\section{Women in their Element}

Selected Women's Contributions to the Periodic System, edited by Annette Lykknes and Brigitte Van Tiggelen, 2019, World Scientific, ISBN 978-981-120628-3; https://doi.org/10.1142/11442

\section{reviewed by Neil Gussman}

My delight in reading the book Women in their Element begins with the title. The play on words in the title says the place of women is in the research lab while echoing the theme made explicit in the subtitle "Selected Women's Contributions to the Periodic System." The work of the 38 women profiled in the book's 500 pages covers four centuries up to nearly present day. From these essays readers learn about some of the contributions women have made to the periodic table of elements over several centuries.

The stories illuminate both the place of women in the history of chemistry and the struggle of taking their place in a world that ranged from skeptical to hostile. But this is a solid work of the history of science which does not lapse into imagined narratives or sentimentality. Each story has solid documentation and is a work of scholarship, yet the stories are entertaining and give real insight into the history of scientific discovery.

In most of the essays in this book, women are shown collaborating to achieve a discovery or insight. For those outside the world of discovery, the dominant narrative focuses on the lone genius who makes a great discovery in a flash of insight. But those moments of genius came most easily to those who had support by teams of collaborators, trained assistants, and the machinery of the modern university system. The collaborative method is how most science is done, and this book shows pioneers in chemistry as pioneers in collaboration.

The book is divided into seven parts covering large themes in chemical discovery. Since the book is part of the celebration of the Year of the Periodic Table in 2019, it's appropriate that the biggest sections are parts 2 and 4, with 7 and 10 essays respectively:

Part 2-The Glory of Analytical Chemistry: The Elements Multiply

Part 4-Clusters of Women in Radioactivity

Part 2 begins with "Elementary Chemistry: Mrs. Jane Marcet and the Popularisation of Chemistry." In this essay we learn how one woman who knew many leading chemists at the beginning of the 19th Century brought chemical science to the general public. One of her "Conversations in Chemistry" is reproduced in the essay, showing how Marcet explains chemistry to

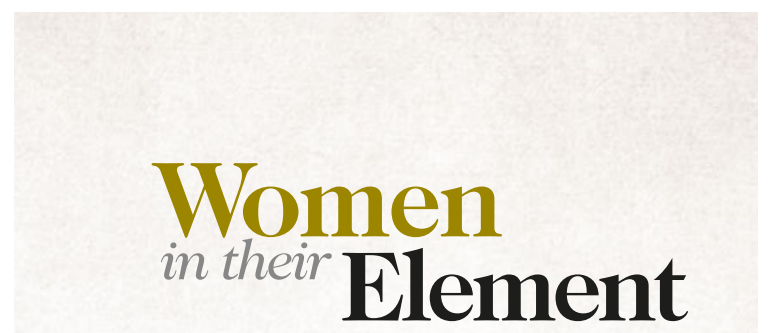

Selected Women's Contributions to the Periodic System

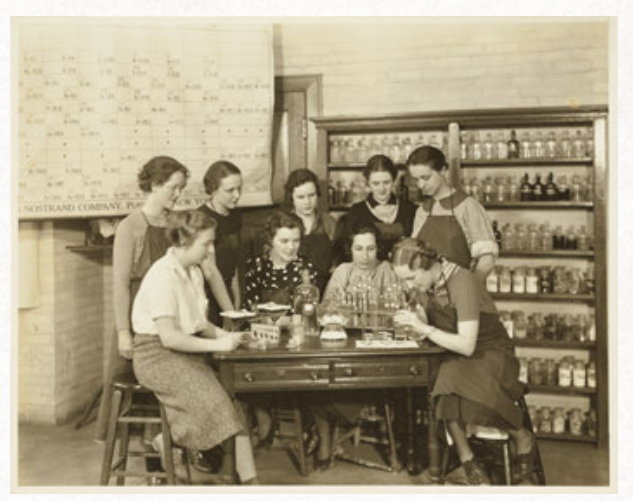

Edited by | Annette Lykknes | Brigitte Van Tiggelen

\section{Woworld Scientific}

someone who sees the elements as "fire, air, earth and water."

On the following page is a table listing the twenty elements discovered by Marcet's friends and contacts: Humphrey Davy, J.J. Berzelius and his students, William Wollaston, Smithson Tennant and Charles Hachett. Her friends discovered more than one in five of the naturally occurring elements.

The ten essays of Part 4 begin, appropriately, with "Marie Skłodowska Curie-Polonium and Radium" and continues through nine more essays on the whole world of chemistry that opened up in the nuclear age. One of those essays concerns the career of Lise Meitner. In contrast with Curie, who won both the Nobel Prize in both Physics and Chemistry, Meitner was nominated 19 times for the chemistry prize and 29 times for the physics prize and won neither. But the woman who discovered protactinium was eventually enshrined in the Periodic Table of Elements when the element 109 was named meitnerium.

Throughout the rest of the book are essays that illuminate the worlds women of discovery inhabited. The second essay in Part 1 is on Émilie du Châtelet. It is a fascinating story of a short, brilliant and tragic life. In 
Part 3 are six essays on how the development and use of new instruments change chemistry and chemical discovery. Part 5 and 6 show the reader many aspects of "Big Science" and the interface between science and industry. Part 6 ends with the fascinating story of Reatha Clark King and her work with fluorine. Part 7-"Social Activism, Sisters in Arms" ends with two essays on the uses and dangers of lead; a look at the darker side of the century of chemical discovery.

The thematic division of the book continues into the three indices at the book's end. There is an Element Index which includes old and new element names, so fire, air, earth and water are listed; a Name Index with organizational names as well people, and a General Index for everything else.

Sweden is the only country listed in the Element Index. Under Sweden are the fifteen elements discovered in this Nordic country that is the home of Alfred Nobel. Radium is the element with the most references in the index, partly because Marie Curie is the most referenced name in the Name Index. The indices are very useful and fun to browse to look for themes in the book. The International Union of Pure and Applied Chemistry is referenced six times in the Name Index.

The book could be used in many ways for those studying women in chemistry, scientific innovation, the history of discovery of elements, as well as larger themes of radioactivity, social activism and the history of science. Women in their Element brings together 38 stories over four centuries that put women at the center of the long story of discovery that takes the world from "fire, air, earth and water" to the Periodic Table of Elements in all of its complexity.

\section{For Science, King \& Country: The Life and Legacy of Henry Moseley}

\author{
Roy Macleod, Russel G. Egdell, and Elizabeth \\ Bruton (eds.) Uniform Press, 2018. 328 pp.-ISBN \\ 9783132012417
}

\section{reviewed by D. Brynn Hibbert}

Henry ("Harry") Gwin Jeffreys Moseley (1887-1915) was, or perhaps would have been, the pin-up scientist of a world entering the atomic age. In this well-produced, extensively-illustrated collection of essays coming from thirteen scholars we have "a more detailed analysis" of his life and research as promised by the editors in the preface to the book. They were prompted by the 2015 exhibition Dear Harry ... Henry
Moseley: A Scientist Lost to War at the Museum of the History of Science at Oxford [1]. Roy MacLeod, Historian of Science, and Russell Egdell, Inorganic Chemist, explain in the introduction that Moseley's brief life, but long legacy, can only be seen through the comparative lenses of history, science, and the history of science. They do justice to each of these.

In some ways the science is straightforward. With hindsight and our present knowledge of atomic structure we read Moseley's two papers The High-Frequency Spectra of the Elements published in 1913 and 1914, as nailing the concept of atomic number, which he identifies "with the number of positive units of electricity contained in the atomic nucleus". But there is still some confusion as to the exact nature of "Moseley's Law," as detailed by John Heilbron (Chapter 10), the author of the first biography of Moseley in 1974. Russell Egdell's account of "X-ray spectroscopy 100 years on" (Chapter 9 ) shows how ubiquitous $X$-rays have become with the inevitable miniaturisation leading to spectrometers in scrap yards and even in space, spawning acronyms galore (in surface analysis alone: XRF, ESCA, XPS, XAS, EXAFS, NEXAFS, SEXAFS, XANES, TXRF, PIXE [2]). As an analytical chemist, I might take up MacLeod and Egdell's assertion that “... X-ray spectroscopy did develop to become arguably the most important of all chemical analytical techniques, ...". My chromatographic and mass spectrometric colleagues might wish to argue, but we should not be so churlish, having rather few war heroes in our ranks.

To a contemporary audience the burning question must be whether Moseley would have won a Nobel Prize, and whether in Physics or Chemistry? There are several contenders and it may be unkind (to Barkla) to suggest the work of C. G. Barkla, recognised in 1918, was a "posthumous tribute to Moseley," as Robert Friedman raises in his introduction to Chapter 6 . This is a fascinating chapter that looks at the deliberations of the five-member Nobel Committee for Chemistry, augmented by the great chemist Arrhenius. In a section "Biased Neutrality" the problems of a Germany-leaning neutral country (Sweden) Friedman tells us what difficulties the Nobel Committees faced, not being able to postpone the prize in wartime. Friedman sums up "Today Henry Moseley stands as one of the greatest scientists of the past century, we do not need the award of a Nobel Prize to command our appreciation and respect."

Earlier, in Chapter 4, Eric Scerri puts Moseley in context of the work that was happening around him. Antonius van den Broek is credited with the concept of the ordering of elements on a whole number scale, and 